\title{
Approaches to formation of strategies for development of administrative territories
}

\author{
Oleksii Klok ${ }^{1,}$, Olha Loseva ${ }^{1 *}$, Oleksandr Ponomarenko ${ }^{1}$ \\ ${ }^{1}$ Simon Kuznets Kharkiv National University of Economics, Kharkiv, Ukraine
}

\begin{abstract}
The article studies theoretical and methodological bases of the strategic management of the development of administrative territories, considers the essence of strategic management and formulates the advantages of using it in management of administrative territory. Based on the analysis of the key provisions of the EU regional policy, the strategy of "smart specialization" is considered as the most common approach to territorial development. Using the experience of the countries of the European Union as a basis, a BPMN diagram, describing the conceptual bases for the formation of a competitive territory strategy, was built. Practical approaches to the formation of strategies for the development of administrative territories operating in Ukraine, regulatory acts, in particular, that had a direct impact on the formation of the existing model of strategic territorial management, were analyzed. The main requirements to the content of the strategic plan were considered and the list of key provisions and analytical methods (socio-economic analysis, comparative analysis, SWOT-analysis, PESTLE-analysis, sociological analysis) was formulated. Using the comparative legal analysis of the experience of the European Union as a basis, a number of features can be highlighted that must be taken into account in the process of forming the administrative territory development strategy.
\end{abstract}

\section{Introduction}

Methods of strategic management, which arose in view of the evolution of management systems under the influence of globalization, instability of environment and changes in the nature of competition, were first used by micro-level systems and only over time entered the practice of managing non-profit organizations, the state and its individual territories. Comparing previous years, more attention is paid to the strategic management of territorial development, as managers have become aware of the effectiveness of its use. At the present stage, the strategic management of administrative territories in Ukraine has a non-systemic nature and low efficiency in the use of tools, remains a poorly studied area, requires improvement of systems and approaches with the purpose of their further implementation.

Ukraine's integration into the European Union is impossible without an adequate practice of using strategic management in territorial development. Summarizing the current situation in Ukraine, it can be stated that all regions are characterized by the same problems

* Corresponding author: olha.loseva@hneu.net 
of socio-economic development: uncertainty of strategic priorities, orientation of program documents to the use of extensive development factors, disproportionate nature of development.

\section{Methodology}

The theoretical and methodological foundations of strategic management of administrative territories development are presented in the studies of representatives of various scientific schools. The increasing degree of Ukraine's involvement in the world economy, in the processes of integration, in particular, internationalization and globalization, requires increasing attention to the world experience in territorial development. The implementation of the world experience allows you to act faster and increase effectiveness of managerial decisions. The information base for the study is legislative and other regulatory acts on the formation of strategies for the development of administrative territories, strategic planning, local self-government. The studies of Ukrainian and foreign authors, published in monographs and scientific journals, including the work papers of European Commission (EC), the Organization for Economic Co-operation and Development (OECD), Global Practitioners Network for Competitiveness, Clusters and Innovation (TCI) were analyzed.

The purpose of the study is to analyze the practical approaches to the formation of strategies for the development of administrative territories operating in the European Union and Ukraine on the basis of the theoretical and methodological support of the strategic management of administrative territories development.

A number of general scientific methods have been used to achieve this objective, such as: retrospective analysis; comparative-legal analysis; idealizations and analogies; content analysis; theoretical generalization.

\section{Formation of Strategies for Development}

\subsection{Strategic Management}

Strategy is more than objectives and actions. Strategy, in particular, is the choice of where and how to compete. Strategic management is a focused management activity in accordance with the chosen strategy, which allows us to function effectively in interaction with external environment using all possible potential, that is, a stable view of current activities, to achieve future objectives with constantly changing internal and external parameters [1].

The advantages of using the strategic management of the socio-economic development of the administrative territory include: raising the level of scientific and practical justification of the proposed activities; possibility to coordinate one's activities as efficiently as possible, the expanded list of participants involved in planning; prioritization and coordination of tasks between the performers, increasing the effectiveness of the managerial decisions made; decomposition into strategic and operational objectives; compilation of individual plans and programs into a single system for development of the territory; assessment and use of competitive advantages, potential of the territory; use of material and financial resources of subjects of various forms of ownership; development of territorial communities .

The development and implementation of an effective strategy for development of an administrative territory requires the experience and technical knowledge of managers of this level. The presence of professionals in narrow subject areas is not enough; there is a necessity of professionals who are able to look through the prism of politics, which greatly complicates the ability to create a quality strategy at the level of basic territorial units. 
There is no consensus in the economic literature regarding an approach that would include the necessary elements of the system of administrative territory strategic development. However, the formation of the strategy involves a clear vision of the following provisions: identification of the main types of economic activities or scientific and technical areas in which the territory can compete; analysis of current or potential unique resources which may be used to strengthen competitive positions; identification of all possible participants and interested individuals who will be involved in strategic management; assessment of the level of interrelation of the region with external agents; understanding of one's own structural peculiarities, including the degree of concentration, polarization, specialization.

\subsection{The Experience of the European Union}

In order to overcome the systemic crisis phenomena in the EU economy, in 2010 the new European economic development strategy for the next 10 years was adopted - "EUROPE 2020: A strategy for smart, sustainable and inclusive growth". Based on the principles of reasonable, sustainable and comprehensive growth, five main areas of activity are assumed: employment; research and innovation; climate change and energy; education; fight against poverty.

In 2013, the parliament of the European Union defined the "Smart specialization strategy" as the national or regional innovation strategies which set priorities in order to build competitive advantage by developing and matching research and innovation own strengths to business needs in order to address emerging opportunities and market developments in a coherent manner, while avoiding duplication and fragmentation of efforts [2]. The idea of smart specialization is not new, but is only a modernized long-term practice of the European Union. Fig. 2 presents the process of developing a strategy for smart specialization by building a BPMN diagram.

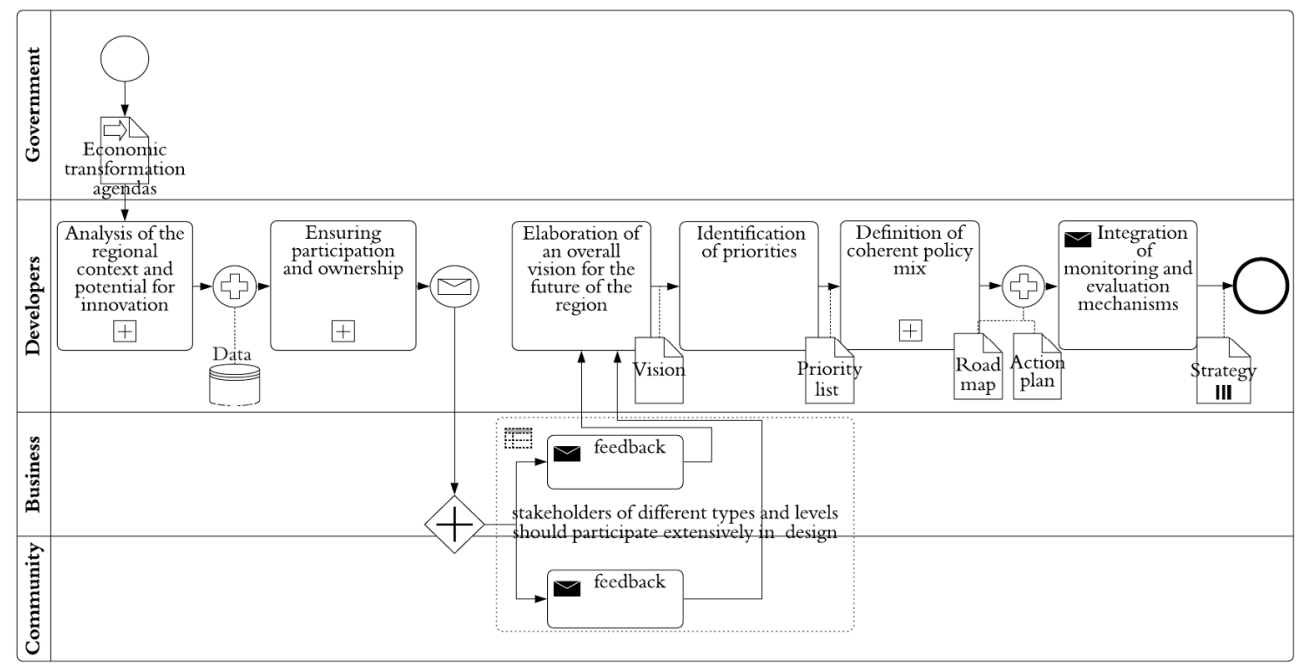

Fig. 2. Process of developing a strategy for smart specialization

In recent years, more than 100 smart specialization strategies (S3) have been developed in the EU, mainly at the regional level. Basically generation unique assets and capabilities 
based on the distinctive industry structures of regions and knowledge bases include: objectives ("why"), content ("what"), process ("how" and "by whom"), role ("where") [3].

The development of administrative territories is the process that requires efficient and effective institutions, as well as close cooperation between government, business and society at every level. Attaching due importance to this matter, the EU regional policy is an ongoing process of revision and adjustment, to ensure development in the dynamic environment. The experience of the European Union is the development of regions, which is based on three key assets: social capital, leadership, new management tools and three functions (learn and introduce innovations, build channels of interconnection, generate ideas).

\subsection{Strategies of development of administrative territories in Ukraine}

At the beginning of the 21 st century, positive transformations, regarding the modernization of the management model, took place in Ukraine, which resulted in the formation of a qualitatively new state regional policy. The process of looking for relevant and effective ways of development of administrative territories in order to reduce uncertainty and timely response to the challenges of modernity is constant, regardless of the level of a administrative-territorial unit. The decisive role in shaping the strategies of economic development, including the system of strategic management of the territory development, belongs to the President of Ukraine, the Cabinet of Ministers of Ukraine, developers of national development programs, scientific, political and public institutions.

The formation of the foundations of the system of forecasting and program documents of the economic and social development of the country, individual sectors of the economy and individual administrative-territorial units by adopting the Law of Ukraine "About the State Forecasting and Development of Programs of Economic and Social Development of Ukraine" can be considered a significant event that had a direct impact on the development of strategic management in Ukraine [4].

Since 2001, Ukraine has the acting Concept of State Regional Policy as a component of the national strategy of socio-economic development of Ukraine. The most significant results for the development of conceptual approaches to strategic management can be considered: the formation of a network of regional development agencies; improving mechanisms of strategic state planning of regional development, the system of national and regional forecasting and planning of socio-economic development; creation of economic, organizational and legal prerequisites for implementation of the basic principles of sustainable, balanced development of the regions [5].

Establishing a single procedure for elaborating strategies of the development of basic administrative and territorial units of Ukraine (regions) with the adoption of the Order "On Adopting Methodological Recommendations for the Formation of Regional Development Strategies" (2002) can be considered the starting point for the introduction of a modern system of strategic management of administrative territories in Ukraine[6].

The strategic regional development plan should include: introduction with a short justification of the objective and prerequisites of strategy development; descriptive and analytical part, detailing the geographical, historical, demographic, economic and social characteristics, in which the analysis and assessment of the actual state of region's development is done; vision of the future - reflection (generalization) of the most common and long-lasting ideas about the prospects of the development of the region and the life of its population, the mission of the region; characteristics of competitive advantages and limitations of the region's development (SWOT-analysis); strategic objectives (directions) and step-by-step action plans with a detailed description of the events, deadlines, executives in charge, sources of funding; mechanisms for implementing the strategy; team of authors 
involved in the process of territory development strategy formation with indication of their contribution.

Taking into account the basic principles of the world practice of developing strategies, the content and objectives of the Strategy of Economic and Social Development of Ukraine "By Way of European Integration", the first strategies for the economic and social development of individual regions (Volyn, Odessa, Sumy, Ternopil, Khmelnitsky and the city of Kyiv) were adopted in early 2004 [5]. Awareness of the feasibility of using strategic planning and forecasting together with the adoption of the Law of Ukraine "On Stimulation of Regional Development" finds its place in the State Strategy for Regional Development of Ukraine for the period up to 2015 [7]. In connection with significant changes in the external and internal environment of the country, a new regional development strategy for the period up to 2020 has been operational since 2014. For the previous strategy, priority was given to the implementation of such tasks as: improving the competitiveness of regions and strengthening their resource potential; ensuring the development of human resources; development of interregional cooperation; creating institutional conditions for regional development [7-8].

The analytical methods, generally accepted in Ukrainian practice for formation of the development strategy of an administrative territory, are socio-economic analysis, comparative analysis, SWOT analysis, PESTLE analysis and sociological analysis. The territory profile is formed as a result of a socio-economic analysis. The territory profile is considered as one of the tools for looking for investors, sources of crediting and grants. The comparative analysis is carried out with the aim of positioning the territory in a competitive environment and identifying its own advantages, it helps to find out which of the development strategies against the background of existing strengths and weaknesses is favourable for an effective and efficient response to changes in the external environment and the use of opportunities and minimization of existing risks. The work [9], using the results obtained during the SWOT-analysis, proposes the following variants of strategies for the territories of Ukraine: based on the analysis of strengths and chances (strengthening / building strategy, opportunity realization strategy, binding / correlation strategy); based on the analysis of weaknesses and threats (elimination strategy, minimization strategy, transformation strategy). The use of the PESTLE model is justified by the presence of a significant number of factors affecting the development of the territory, in particular, political, economic, socio-cultural, technological, legal and environmental ones. Sociological analysis is most often carried out through a survey of the population and business representatives in the context of strategic development of the territory. For this, as a rule, a questionnaire is developed which consists of an introduction, a list of questions and personal data.

\section{Conclusion}

The obtained findings suggest significant differences in approaches to the formation of a territory development strategy in the EU and Ukraine. In the global world, 3S trends (Smart, Specialized, Strategic) dominate in developed countries. Smart specialization approach implies not only the identification of potential sectors of specialization, on the contrary, it is aimed at creating reliable and transparent means of identifying and developing new areas of activity at the regional level, allowing to explore and discover new technological and market opportunities [10]. Based on a high level of institutional development, focusing on improving competitiveness, such an approach is extremely difficult to implement into Ukrainian realities. It covers a broad view of innovation that goes beyond research and technology and is supported by effective monitoring mechanisms. Based on the comparative legal analysis of the experience of the European 
Union, it is possible to single out a number of peculiarities that must be taken into account in the process of forming the development strategy of an administrative territory. These include: long-term strategic vision; objectivity of distribution and attraction of resources; strengthening ownership through co-financing and partnerships; institutional architecture of the legal field with a wide range of rules regulating the implementation of the strategy; development of integrated programs; grant programs; financial management and control, economic development planning, as well as identification and motivation of relevant stakeholders; monitoring and evaluation; transparency of the strategy implementation process.

Actual strategies of socio-economic development of the regions were developed up to 2020 , thus, in the near future, work will begin on the formation of new strategies. Based on the results of monitoring and evaluation of current strategies, developers will not only have to eliminate current shortcomings, replacing tools that have demonstrated low efficiency, but also rethink approaches to the formation of development strategies. Strategic management requires a high degree of coordination between the government and other subjects involved in the strategy development process.

\section{References}

1. M. Avramenko, Conceptual and methodological fundamentals for strategic management of territorial development in conditions of transformation processes: Scientific professional publication of state administration of Ukraine, 1, 214-224. (2015).

2. D. Foray, J. Goddard, I. Goenaga, M. Landabaso, K. Morgan, K, C. Nauwelaers, R. Ortega-Argilés, Guide to Research and Innovation Strategies for Smart Specialisation. Brussels: European Commission, 121. (2012).

3. C. Ketels, What Is Regional Strategy? Lessons from Business Strategy, 3, 37-54. (2015).

4. About the State Forecasting and Development of Programs of Economic and Social Development of Ukraine (2000) [online]. Available at: http://zakon2.rada.gov.ua/laws/show/1602-14

5. Strategy of economic and social development of Ukraine "By Way of European Integration". (2004) [online]. Available at: https://zakon.rada.gov.ua/laws/show/493/2004.

6. On Adopting Methodological Recommendations for the Formation of Regional Development Strategies (2002) [online]. Available at: http://zakon.rada.gov.ua/laws/show/z0632-16\#n13.

7. State Strategy of Regional Development of Ukraine for the Period up to 2015 (2006) Available at: https://zakon.rada.gov.ua/laws/show/1001-2006-п.

8. State Strategy for Regional Development for the period up to 2020 (2014) Available at: https://zakon.rada.gov.ua/laws/show/385-2014-п.

9. O. Berdanova, V. Vakulenko. Strategic planning of local development. Practical guide, 88 p. (2012).

10. C. Nauwelaers, J. Blazek, E. Magro, P. McCann, K. Morgan, R. Ortega-Argiles, J. Wilson, Smart Specialisation For Regional Innovation: European Union, 145. (2015). 